International Journal of Current Advanced Research

ISSN: O: 2319-6475, ISSN: P: 2319 - 6505, Impact Factor: SJIF: 5.995

Available Online at www.journalijcar.org

Volume 6; Issue 4; April 2017; Page No. 3239-3247

DOI: http://dx.doi.org/10.24327/ijcar.2017.3247.0235

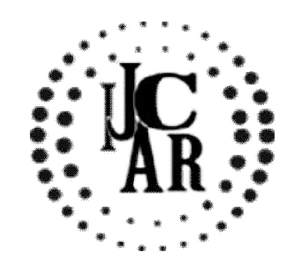

Review Article

\title{
THE CONCEPT OF VRANA - A REVIEW
}

\section{Ganapthirao.I*., Naikar Ashok., Biradar Vijay and Halli Chandrakanth}

Depatrment of Post Graduete Studies in Shalya Tantra, N.K.Jabshetty Ayurvedic Medical Collage \& P.G.Centre, Bidar-585403(Karnataka)

\section{A R T I C L E I N F O}

\section{Article History:}

Received $11^{\text {th }}$ January, 2017

Received in revised form $19^{\text {th }}$ February, 2017

Accepted 22 $2^{\text {nd }}$ March, 2017

Published online $28^{\text {th }}$ April, 2017

Key words:

Vrana, Dushta Vrana, Sadhyo Vrana.

\begin{abstract}
A B S T R A C T
Ever since the life originated, human being has been susceptible to injury, which made him to think about healing from very early stage of development. Vrana are a frequently encountered problem in the present era produced mainly due to trauma or pathologic insult and may cause long-term agony to the patients. In this review article, we have tried to describe different types of Vrana, their lakshanas, sthanas, Sadhyasadhyata and their management according to different Acharyas in Ayurveda. Efforts have also been made to clearly describe Sadhyo Vrana and Dushta Vrana and their lakshanas.
\end{abstract}

Copyright $₫ 2017$ Ganapthirao.I et al. This is an open access article distributed under the Creative Commons Attribution License, which permits unrestricted use, distribution, and reproduction in any medium, provided the original work is properly cited.

\section{INTRODUCTION}

Ayurveda is a science of life and is believed to exist as long as the origin of life on this earth as is mentioned in Charaka Samhita. Ever since the life originated, human being has been susceptible to injury, which made him to think about healing from very early stage of development. In Ayurveda, particularly Acharya Sushruta has mentioned various types of vrana $^{l}$ and their management ${ }^{2}$, which is of prime importance in any surgical practice. In recently, brilliant progress of surgery in various fields has immensely reduced the incidence of wound infection by decreasing the impediments associated with wound healing to certain limits. Still wound management continues to be a matter of speculation.

\section{Definition of Vrana}

"Vrana Gatra Vichurnane,"

"Vranayati iti Vranaha”.-Sushruta Chikitsa Sthana 1/6

"Gatra" means tissue (body tissue or part of body)

"Vichurnane" means destruction, break, rupture and discontinuity (of the Body or tissue)."The destruction / break / rupture / discontinuity of body tissue /part of body, is called Vrana."

In Sushruta Samhita ${ }^{3}$ Acharya Sushrutha has clarified that as "the scars of a wound never disappear even after complete healing and its imprint persists lifelong, it (the lesion) is called vrana by the wise".

\section{*Corresponding author: Ganapthirao.I}

Depatrment of Post Graduete Studies in Shalya Tantra, N.K.Jabshetty Ayurvedic Medical Collage \& P.G.Centre, Bidar-585403(Karnataka)

\section{Classification of Vrana}

Vrana are broadly classified into two according to their origin and etiology ${ }^{4}$.

1. Nijavrana and

2. Aganthuja vrana

Nijavrana are formed by vitiated doshas while Aganthuja vrana are caused by external factors such as incision, punctures, lacerations, poisoned cuts, bruises etc. It can also be caused by bites of men, animals, birds, reptiles etc. Vrana are again classified into two on the basis of the Dosha dushti, they are Dushta vrana and Shudha vrana. Vrana having more dosha dushti is called as Dushta vrana and those having less or no dosha dushti are called as shudha vrana ${ }^{5}$

Another type of vrana is the SadhyoVrana which is manifested by external causes. They include accidental wounds or traumatic wounds and surgical wounds. So these sadyovrana can also be called as aganthujavrana or sudhavrana ${ }^{4}$. They cannot be called as an Ulcer because the inflammatory swelling and the suppurative processes are absent here. They can be correlated with "wounds" described in Western science. This is why almost all the Acharyas have classified sadyovrana as a separate chapter.

\section{Panch Lakshana Nidana}

\section{Nidana}

Two types of vrana nidana have been mentioned in all classical texts of Ayurveda.

1. Nidana of Nijavrana.

2. Nidana of Aganthujavrana (Sadyovrana) 
Nijavrana are caused by the deranged doshas due to their respective etiological factors ${ }^{6,7}$. Aganthujavrana are caused by either internal or external injuries due to living or nonliving objects ${ }^{8}$. The living causes of sadyovrana are bites of men, birds, ferocious animals etc. The non-living causes may be classified as physical, mechanical, chemical and toxic. Among them fall, hit blow etc. are physical causes. Injuries inflicted due to piece of wood weapons, bones etc. are mechanical factors. Wounds caused by acid or alkali can be considered as chemical factors.

\section{Samprapthi}

The Samprapthi is also divided into two depending upon the type of vrana.

- Nijavrana Samprapthi

- Aganthujavrana Samprapthi

In Nijavrana the tridoshas by their respective etiological factors get deranged and getting lodged in the Vranaadhishtana produces vrana. Aganthujavrana are caused due to direct external injuries to the body. The local structures i.e. twak mamasa, sira, snayu, asthi, marma etc. are disrupted according to etiological factors producing sadyovrana or aganthujavrana. Here structural derangement occurs first followed by vitiation of doshas. If at this stage it is not treated it progresses into Dushtavrana. In nijavrana the paka takes place first by the vitiation of doshas and then it manifests as Dushtavrana. Every aganthujavrana becomes a nijavrana within a period of 7 days.

\section{Purva Rupa}

The prodromal symptoms of vrana is shotha, i.e. a localized swelling which is due to Dosha dushti and is according to respective doshas. It is seen only in nijavrana, Madhava Nidana has described the prodromal symptom of vrana as "Ekadeshotthitha Shotha".

\section{Rupa}

Two types of lakshana ${ }^{9}$ have been seen in vrana, viz.

1. Saamanya lakshana - Pain is present in all types of vrana in accordance with the dosha.

2. Vishesha lakshana - It is the lakshana of dosha dushti which is according to the doshas involved in the manifestation of vrana.

\section{Classification of Nijavrana}

There are 15 types of nija vrana according to Acharya Sushruta and Vagbhata ${ }^{10}$. They are as follows:

\section{Vataja}

It has a brown or vermilion colour and it exudes a thin slimy cold secretion. The characteristic symptom of this vrana is the various type of pain like throbbing, pricking, piercing etc. This has no tendency to extend much more, but the complete destruction of tissue is a notable character of this type.

\section{Pittaja}

Rapid growth is the specificity of pittaja vrana. It assumes a bluish yellow colour, exudes a hot secretion resembling kimsuka flower and associated with burning sensation.The surrounding of this vrana has small yellow colored eruptions.

\section{Kaphaja}

It is a thick and compact covered with large number of vessels and membranous tissues, grey in colour slightly painful, hard and feeling of heaviness. It exudes a thick cold, white and slimy secretion. This type of vrana is noticed with severe itching and is found to be extended and raised around its margins.

\section{Shonithaja}

This vrana looks like a lump of red coral. It is surrounded with black vesicles and pustules; it smells like a strong alkali. It is painful and produces a sensation of fumes escaping out. Bleeding is the notable character of this vrana. The specific symptoms which are seen in pittaja vrana supervene in this vrana.

\section{Vata Pittaja}

It is manifested due to derangement of vayu and pitta. It is characterized by its pricking and burning pain. It is red vermilion colour. It is sensitized by escapes of fumes from it. The colour of its secretion is same as seen in Vataja and Pittaja type.

\section{Vata Kaphaja}

It is characterized by severe itching, pricking pain, in duration constant discharge of cold slimy secretion.

\section{Kapha Pittaja}

It is guru, ushna and yellow in colour. It is marked by burning sensation and it exudes a pale yellow colored secretion. This is the peculiarity of this vrana.

\section{Vata Shonithaja}

It is dry, thin and largely attended with piercing pain and loss of sensation. It exudes blood by the combined doshas respective

\section{Pitta Shonithaja}

It is manifested by the combination of pitta and raska. It has a colour which resembles the surface cream of clarified butter. It has got the smell of fish washed water. It is soft spreading and secretes a hot blackish liquid.

\section{Kapha Shonithaja}

It is red in colour, thick, slimy, glossy and indurate. Itching and yellow colored secretion is the noticeable character of this vrana.

\section{Vatapitta Kaphaja}

It produces pain as if cut with a sword. Its secretion is peculiar to each of the doshas predominant.

\section{Vata Pitta Shonithaja}

It gives throbbing, pricking and burning pain. It discharges a thin yellowish fluid and produces sensation as if fumes are escaping.

\section{Pitta Kapha Shonithaja}

It has got red colour. Itching, suppuration and burning sensation are also found. It emotes a thick grayish blood stained secretion. 


\section{VataKapha Shonithaja}

It is marked by the itching, throbbing, tingling sensation and thick grey blood stained discharge.

\section{VataPitta kapha Shonithaja}

It is characterized by a sensation as if it is burnt and lacerated. It is largely sensitized by throbbing, itching, pricking and burning pain with complete loss of sensation in the affected part. Redness, suppuration, various kinds of colour, pain and secretion are its other features.

Acharya sushruta consider 16 types of nijavranas by adding shudha vrana to $\mathrm{it}^{10}$.

\section{Classification of Sadyo Vrana}

Acharya Vagbhata gives a clear description of Sadyovranas ${ }^{11}$ on the basis of their severity. They have been grouped into eight even though they are unlimited. They are as follows:

\section{Ghristham}

It is caused by slight injuries such as Abrasion through friction and is characterized with heat and secretion. Here the outer layer of the skin or the epithelium is ruptured with oozing out of lasika or saraktha lasika.

\section{Avakritta}

It is more deeply affected than Ghrishta and is characterized by discharge of blood.

\section{Vichinna}

It is deep injury to the internal organs.

\section{Pravilambi}

It is the injury deeper upto the bones. These are lacerated wounds which are mostly seen in clinical practice mainly caused by accidents and industrial injuries. The wounds are mainly due to blunt objects and are associated with a certain amount of tearing so that the edges and surfaces of the wounds are jagged and contain moderate amount of devitalized tissues.

\section{Pathitha}

Here a part of the body will be separated and have a break in the continuity.

\section{Viddha}

It is manifested by weapons having sharp edges which pierce on to the body except the region of koshta (thorax, abdomen, bladder etc.).

\section{Bhinna}

It is the vrana produced by sharp instrument piercing into the koshta.

\section{Vidalitha}

It is particular type of vrana where impact of the injury causes crushing of the bones and soft tissues including the bone marrow and blood. It not only extends to the deep structures but is extended widely also. But Sushruta tries to differentiate the size and shape of Sadyovrana. He says that some of the Sadyovrana may be elongated, rectangular, triangular, circular, semicircular, extended, zig-zag shape, hollow in the middle like sharava or having the shape of Yava dhanya (barley corn bulged out at the middle).

Sushruta again classifies these into six types according to their lakshanas ${ }^{12 .}$ They are as follows:

\section{Chinnam (excised)}

It is a wound which is an open cut transversely or longitudinally and where the limbs are separated from the body.

\section{Bhinnam (penetrating)}

It is caused by piercing of the sharp instrument like spear or sword into the body cavities in which there is only a little discharge of blood or lasika.

\section{Viddha (punctured)}

It is a wound which is produced by a sharp instrument in any part of the body, other than the koshtha a part of the instrument is left inside in some cases.

\section{Kshatha (incised)}

It is having the signs and symptoms of both cut and perforation (china and bhinna) and it is uneven in appearance.

\section{Picchitha (lacerated)}

A part of the body with the local bone crushed between the folds of a door or by a blow becomes swollen and covered with blood and marrow.

\section{Ghrishtha (abrased)}

In this type the skin is mainly affected due to friction or slight injury and it is called as abrasions. Burning sensation and a little secretion in the affected part is the characteristic of this type.

In Ashtanga Sangraha the Sandyovranas are broadly classified into three types namely

\section{Chinnam}

It is the one in which the particular part of the body is separated into two. He again divided each of these into several groups according to the degree of their injury.

It is of five types as follows

a. Ghrishta - slight injury

b. Avakritha - injury extending up to the mamsa.

c. Vicchinna - in it there is involvement of internal structures.

d. Pravilambi - injury may be deep extending up to the bones and ligaments.

e. Pathitha - part of body is separated from the whole.

\section{Viddham}

Injury caused by weapons or instruments which pierces the skin and internal structures. It is of 8 types

a. Anuvidha - the extension of shalya is up to mamsa

b. Uthunditha - Shalya causing protrusion of the skin

c. Athividha - Shalya goes deep into the internal structures

d. Nirvidha - Shalya enters through one side of the body and comes out through the opposite side. 
e. Anubhinna - It is manifested in any part of the body other than the Koshta

f. Bhinnothunditham - It is manifested in the Koshta g. Athibhinna and Nirbhinnam - same as above.

\section{Picchitham}

It is the vrana where the body part is crushed by the injury and flattened along the bone of the affected part. It is of two types

1. Savrana picchitha - here the body part is crushed, blood and marrow oozes out.

2. Avrana picchitha - the bone is fractured and there is no external wound, Harita Samhita mentions their characters under the heading of Doshaja vrana and Dushta vrana.

Table 1 Sadyovranas according to different Acharyas

\begin{tabular}{ccccc}
\hline Su. Sa. & A.S. & A.H. & Ma. Ni. & Sh. Sa. \\
\hline Chinnam & Chinnam & Ghrishtham & Chinnam & Avakritham \\
Bhinnam & Viddham & Avakritham & Bhinnam & Vilambitham \\
Viddham & Picchitham & Vicchinnam & Viddham & Chinnam \\
Kshatham & - & Pravilambitham & Kshatham & Bhinnam \\
picchitham & - & Nipathitham & picchitham & Parachalitham \\
Ghrishtham & - & Viddham & - & Viddham \\
- & - & Bhinnam & - & - \\
- & - & Vidhalitham & - & Nipathitham \\
\hline
\end{tabular}

Charaka has described another classification of vranas depending on theircharacters ${ }^{13}$. They are 20 in number.

1. Kritya vrana - (incisible) in which surgical measures can be done.

2. Akritya Vrana - (Unincisible) in which surgical procedures like Chedana etc. are impossible and is difficult to treat.

3. Dushta Vrana - (Defective) in which dosha dushti has implied.

4. Adushta Vrana- (Undefective) in which dosha dushti is less and is notputrified. It is the shudha vrana described by other Acharyas.

5. Marmashritha Vrana- It is the vrana located in the marmas like Hridaya etc.

6. Amarmashritha Vrana - it is which does not affect the vital parts of the body.

7. Samvrutha Vrana - in which the mouth of vrana is narrow

8. Vivrutha Vrana - in which the mouth of vrana in wide.

9. Daruna Vrana-vrana which is indurated in nature.
10. Mridu Vrana - which is soft to touch

11. Sraavi Vrana - characterized by profuse discharge

12. Asraavi Vrana - in which there is no discharge.

13. Vishayuktha Vrana- which is contaminated with toxins

14. Visharahitha Vrana - not contaminated with toxins

15. Vishama Vrana- having an irregular shape and indefinite size.

16. Sama Vrana - has a definite shape and size

17. Uthsangi Vrana - (Pouchy) it is deep rooted.

18. Anuthsangi Vrana- (Non-Pouchy) it is not deeply rooted.

19. Uthsanna Vrana- in which surface is elevated.

20. Anuthsanna Vrana - in which surface is depressed.

\section{Dushta Vrana}

On the basis of dosha dushti the vranas are again classified as Dushta Vranas and Shuddha Vranas. It is the only one classification which is agreed by Harita Samhita.

He has considered all vranas as Dushta vranas due to the involvement of doshas in its production.

The etiology and pathogenesis of Dushta vranas have been described by Acharya Harita as follows -

- Contaminated food and drinks

- Lifting heavy loads

- Severe exercise

- Emotional factors like anger, fear, grief etc.

\section{Samprapthi (Pathogenesis)}

Due to above mention etiological there occurs destruction in mamsa dhatu which results in oozing of blood from its normal pathway and thus leading to Dushta vranas.

Kashyapa samhita also accepts that doshas are the inevitable factors for the manifestations of Vrana. Vrana is caused not just by the individual vitiated doshas only, but also with the combined vitiation of doshas. Even though the vrana is manifested at first on the skin, later it extends to the deeper structures such as meda, asthi etc. and lastly it results in dushta vrana thus destructing considerable amount of dhatus.

\section{Dushta Vrana Lakshanas}

The vrana may be too narrow or too widened, mouth too hard or too soft, raised from their surface or depressed, too cold or too hot to touch and the colour may be black red-yellow or white and is characterized by extreme temperature.

Table 2 Lakshanas of Dusta Vrana According to various Acharyas

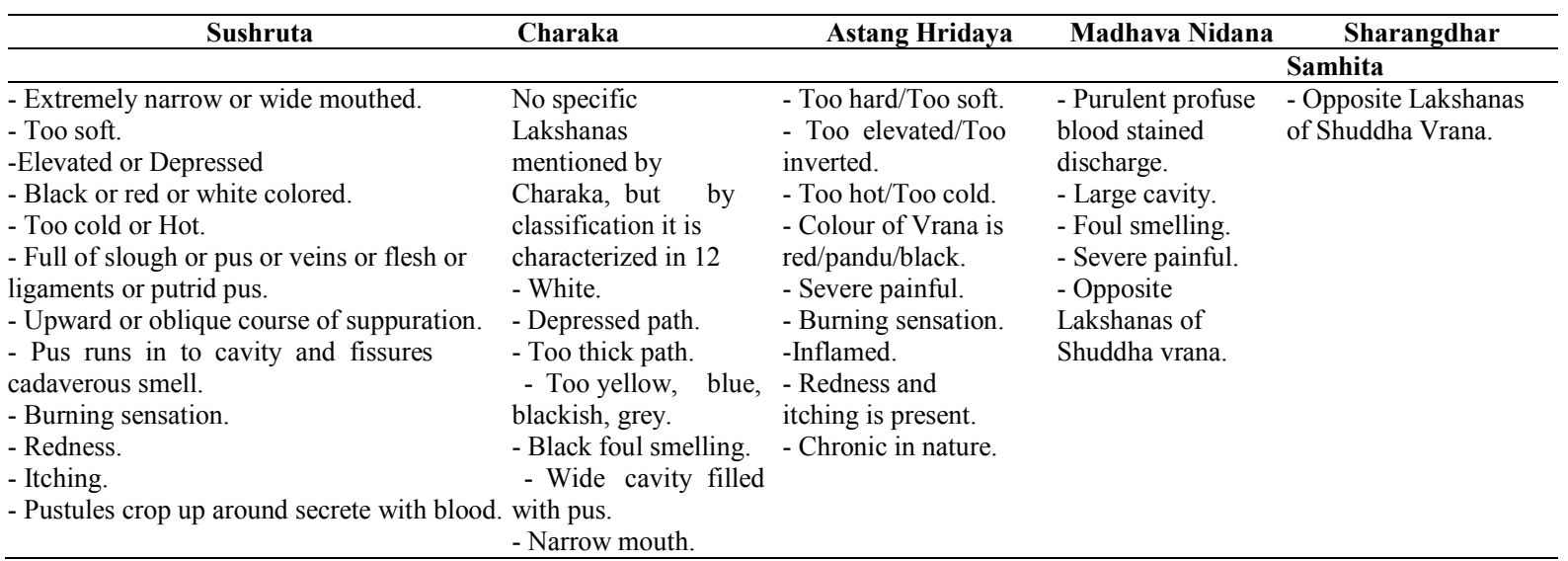


It has a vulnerable appearance having a network of veins, ligaments etc. They are filled with putrid and sloughing flesh accompanied with fetid pus, irregular and indefinite shape. Secretion of dirty fetid pus which runs into fissures and cavities following an oblique or upward course are the specificities of the vrana. The Dushta vrana have cadaverous look and irritating smell and are noticed by extreme pain and burning sensation. Besides these swelling, redness, itching, pustules are seen around the wound. There will be amorphous secretion of impure blood. The vranas will remain unhealed for a prolonged period. ${ }^{14-18}$

The aganthuja vranas may become dushta vrana due to infections or if kept untreated. Charaka classifies Dushta vranas into 12 types according to their appearance. They are as follows:

1. Shwetha - Vrana having pale colour

2. Avasannavartham - Vrana with depressed edges

3. Athisthulavartham - Vrana with thickened edges

4. Athipinjara - Vrana with yellowish red colour

5. Athineela-Vrana with blue or dusky colour

6. Athishyava - Vrana with deep pale colour

7. Athipithaka - Vrana covered with pustules

8. Athiraktha - Vrana with deep red colour

9. Athikrishna-Vrana which is black in colour

10. Athiputhika-Vrana which is extremely putrid

11. Roupya-Recurrent wound

12. Kumbhimukha-Vrana having pinpointed mout

\section{Shudha Vrana}

\section{Characteristic features of Shudha Vrana}

Wound which is not very red, not very pale, not very painful, not very elongated nor having thick edges, having less dosha dushti having the same colour of the tongue and is soft, glossy, smooth and painless, well shaped and having no secretion are considered to be shudha vranas.

\section{Vrana Akruthi}

Vrana assumes a shape which is diffuse, rectangular, spheroidal or triangular or some may be irregular in shape.

\section{Vrana Gandha}

Charaka Samhita has described the vrana gandha i.e. the odour of vranas as 8 in number. The various types of vrana gandha ${ }^{20}$ are namely -odor of ghee, taila, vasa, puya, rakta, Syava gandha, Amla gandha and Puti gandha. Sushruta Samhita has described it based on the predominance of doshas in the manifestation of vranas. They are 5 in number as
1. Vataja - Katu gandha
2. Pittaja-Teekshna gandha
3. Kaphaja-Ama gandha
4. Rakthaja - Louha gandha
5. Sannipatika - will have the smell of all above vranas.

\section{Vrana Sravas}

Vrana sravas are the secretions from vranas. By studying the various vrana sravas we can identify the type of vranas according to their doshas and dushyas. According to Acharya Charaka, they are 14in number, namely - Laseeka srava, Jala srava, Puya srava, Raktha srava, Haridra srava, Aruna srava, Pinjar srava, Kashaya srava, Neela srava, Harita srava, Snigdha srava, Ruksha srava, Sita srava, Asita srava. Acharya Sushruta says the vrana sravas may be varied depending upon the location where the vranas are manifested. Watery secretion is specific for superficial wounds. For vrana of mamsa dhatu the secretion is like ghrita. Profuse bleeding is associated with injured sira. In snayu, the vrana produces oily thick secretion. In bone the vrana produces the secretion like washed sukthi. Koshta vrana produces secretion of blood, urine, fecal matter and pus.

Table 3 Lakshana of Shuddha Vrana according to various Acharyas

\begin{tabular}{|c|c|c|c|c|}
\hline Sushruta & Charaka & Sangrahakar & Hridayakar & Madav Nidana \\
\hline $\begin{array}{l}\text {-Recent origin. } \\
\text { - Unaffected by the three Dosha. } \\
\text { - Edges with a slight blackish colour } \\
\text { and having granulation tissue. } \\
\text { - Absence of pain. } \\
\text { - Absence of secretion. } \\
\text { - Even surface throughout the wound } \\
\text { area. } \\
\text {-Slimy surface. } \\
\text { - Regular surface. } \\
\text { - No discharge. }\end{array}$ & $\begin{array}{l}\text {-Colour of wound is } \\
\text { reddish black. } \\
\text { - Moderate pain. } \\
\text { - No any type of } \\
\text { elevation and depression. }\end{array}$ & $\begin{array}{l}\text { - No pain. } \\
\text { - No discharge. } \\
\text {-Colour of wound is } \\
\text { blackish. } \\
\text { - Even margins, slight } \\
\text { elevation in the } \\
\text { middle. } \\
\text { - Opposite character of } \\
\text { Dusta vrana. }\end{array}$ & $\begin{array}{l}\text { - Surface of wound is } \\
\text { just like tongue. } \\
\text { - Soft. } \\
\text { - Wound is Un acute. } \\
\text { - Surface is smooth and } \\
\text { normal. } \\
\text { - Absence of pain and } \\
\text { secretion. }\end{array}$ & $\begin{array}{l}\text { - Wound surface is } \\
\text { just like tongue. } \\
\text { - Very soft. } \\
\text { - Slimy. } \\
\text { - Painless. } \\
\text { - Not too much } \\
\text { discharge. }\end{array}$ \\
\hline
\end{tabular}

\section{Vrana Pareeksha}

The acharyas of Ayurveda have classified the examination of Vrana under two broad sections. I. Vrana Pareeksha and II. Vrana Rogee Pareeksha

Vrana pareeksha includes the examination of the wound in details. It includes Vrana sthanas (site), Vrana akruthi (shape), Vrana varna (colour), vrana gandha (odour), Vrana Srava (exudates) and Vrana ruja.

\section{Pancha Lakshana Pareeksha}

The following are collectively called as pancha lakshana pareeksha $^{19}$.

\section{Vrana Varnas}

Vataja vrana is black, red or ash colored or the colour of the bone or pigeon. Pittaja vrana is either blue, yellowish, greenish brown, black, reddish tawny, or flame colored. Kaphaja vrana is either white, pale yellow or glossy.

\section{Vrana Vedana or Vrana Ruja}

Sushruta describes various kinds of pain felt in different types of vranas. Though pain is a characteristic symptom of vata dosha, it may occur variedly in each of doshaja vranas.

\section{Vataja Vrana}

There will be different types of pain such as pricking, piercing, thrashing, cutting, expanding, gnawing, churning, 
shooting, tingling, burning, breaking, bursting, pinching, uprooting, uplifting and pains of a spasmodic character and vanishing without any cause.

\section{Pittaja Vrana}

It is characterized by a sensation of burning pain, a feeling of inhaling heat, osha, chosha, daha etc. present. The same kind of pain is seen in rakthaja vrana.

\section{Kaphaja Vrana}

There will be itching, numbness and slight pain and cold.

Sannipathaja Vrana: Combined nature of pains will be seen.

\section{Vrana Sthana}

Vrana sthanas are also known as vrana asayas. These are the locations where vranas are usually manifested. In Ashtanga Sangraha and Sushruta Samhita, vrana sthanas are 8 in number, namely - Twak (skin), Mamsa (Muscles), Sira (Blood vessels), Snayu (Ligaments), Sandhi (Joints), Asthi (Bones), Koshta (Thorax and Abdomen) and Marma (Vital parts). Acharya Charaka excluded sandhi and substituted in with Medas to the above numbers.
(Cough), Chardi (Vomitting), Athisara (Diarrhoea), Hikka (Hiccough), Swasa (Dyspnea), Vepathu (Tremors).

But Sushruta has not described such types of diseases as upadravas. According to him they are 5 in number. They are gandha, varna, srava, vedana and akruthi. He also describes jwara, athisara, murcha, hikka, chardi, aruchi, aruchi, swasa, kasa, avipaka and thrishna as the upadravas of a vranitha patient. (S. Chi. 1/39, S.Su 28/13-17).

\section{Sadhya Asadhyata}

Sadhya asadhyata of a vrana depends upon three main factors

1. The individual on whom it has manifested.

2. The nature of the vrana

3. Location of the vrana

The individual's age, health, mental stability, body resistance etc. have got important role in enhancing the healing of the vrana.

\section{Sukha Sadhya Vrana}

The prognosis of vrana has been described by most of the acharyas and they give different reasons to describe them.

Table 4 Different features of Vranas

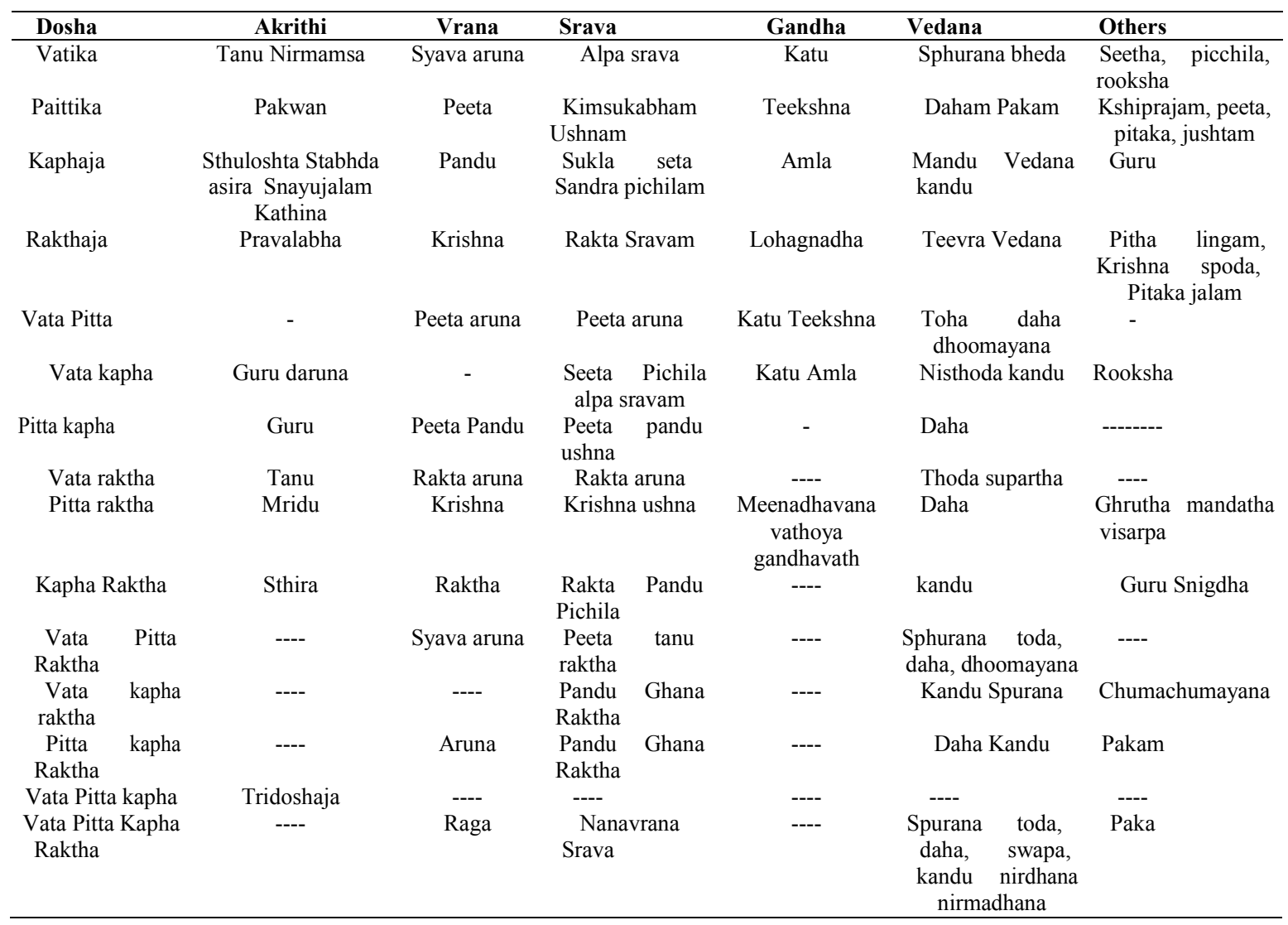

\section{Upadrava of Vrana}

Upadravas of vranas are the complications produced due to vrana. As a matter of fact, these complications are also considered as separate disease entity. Charaka describes 16 Upadravas. They are namely - Visarpa (Erysipelas), Pakshaghata (Paralysis), Sirasthambha (Occlusion in blood vessels), Apathanaka (Tetanus), Moha (Mental confusion), Unmada (Insanity), Vrapa ruja (Acute pain in wound), Jwara (Fever), Thrishna (thirst), Hanugraha (Lock-jaw), Kasa
The vrana manifested in a young individual the healing process with vitalizing principles. Conversely if it is produced in an aged individual the prognosis will be $\mathrm{bad}^{21}$. The locations where the vranas are manifested have great importance in the prognosis. Sushruta describes that the vranas formed on the nithamba, guda, guhya pradesha, lalata, ganda, oshta, prishta, phalakosha, udara, jathru, mukha and abhyantara desha are easily curable. The general health has also got a main influence in the rate of healing. Under condition of ordinary health repair proceeds at a uniform rate 
provided there is no local interference. If the patient had a good health and a strong musculature, he finds a speedy and succession termination. While considering a child the wound heals quickly due to the rapid growth of the tissues. With advancing years, the rate of wound healing would become considerably impaired. Vagbhata says that vranas formed in persons having enough satva bala, good health are easily curable. The shape of the vrana also has good influence in the curability of Vranas. The vranas having circular, extended, conical, rectangular, triangular and square shaped vranas are also curable.

\section{Krichra Sadhya Vranas}

The vranas manifested at the region of akshi (eye), dashana (teeth), nasika (nose), apanga (canthus), nabhi (umbilicus), seevani (sutures), Kaksha (axilla), sandhi (joints) are difficult to treat $^{21}$.

The Bhagandhara vranas which are filled with pus, gas and in which the Shalya is situated inside are also considered as krichra sadhya vranas. The vranas which are narrow mouthed, formed in the vital parts, perineum, and pelvis are also difficult to cure.

\section{Asadhya Vranas ${ }^{21}$}

The asadhya vranas are those associated with chronic diseases like visarpa, jwara, athisara, kasa etc. and those which are manifested in persons having excessive thirst, swasa and avipaka are incurable.
The vranas formed by breaking the kapalasthi with exposure of masthulunga are also incurable. According to Sushruta the vranas cropping up like a mamsa panda, painful with pus inside and characterized by copious secretions with its edges raised like the male genitalia is incurable.

The wound which occurs in a weak and emaciated person which is located within the cavity of the abdomen and which assumes black or yellowish colour and exudes a secretion composed of urine, pus, blood and fecal matter and which finds its outlet both through the mouth and anus making a rumbling, gurgling sound should also be regarded as incurable. Vranas occurring in persons who have lost their mental and physical strength, persons with suffocation, cough, irritation and those vranas at marma paints emanating blood and pus and which do not yield any improvement after continuous treatment are said to be asadhya.

The sadhya vranas turn to be asadhya vranas on account of the following reasons broken snayus, deep wound, snayu emitting pus, infected with microorganisms, broken bones contaminated with poison, bandaging on wrong positions, using excess oily stuffs, severity, constant touch of hairs on vranas, unlimited movements, not keeping up koshta shuddhi through vamana etc. , too much eating, massive emaciation, not following strictly the pathyas prescribed in the Shastras these are the causes making sadhya vranas into asadhyas.

Table 5 Treatment of Nija Vrana described by various Acharyas

\begin{tabular}{|c|c|c|c|c|}
\hline Charaka & Bhela & Vagbhatta & Kasyapa & Bhavprakash \\
\hline (Ch.Chi.25) & (Vrana chi.) & (A.San.Ut.29 & (Ka. Bal. Prati.) & (Bha.chi. \\
\hline & & A.Hr. 4/25) & & 47/17-18) \\
\hline 1.Sodana & 1.Vedana & 1.Vamana & 1.Aptarpan & 1.Lepa \\
\hline 2.Patana & 2.Pachana & 2.Virechana & 2.Parisek & 2.Parisek \\
\hline 3.Vyadhana & 3.Stambhana & 3.Upachara & 3.Upanaha & 3.Vimlepana \\
\hline 4. Chedana & 4.Sosana & 4.Raktamokshana & 4.Sneha & 4.Raktamokshana \\
\hline 5.Lekhana & 5.Ropana & 5.Seka & 5.Samsana & 5.Pachana \\
\hline 6.Prachhan & 6.Chedana & 6.Abhyanaga & 6.Bandhana & 6.Bhedana \\
\hline 7.Sivan & 7.Bhedana & 7.SophaharaLepa & 7.Utkinnaprakasalana & 7.Sodhana \\
\hline 8.Avapidana & 8.Lekhana & 8.Svedan & 8.Kalka & 8.Ropana \\
\hline 9.Nirvapana & 9.Sphutana & 9.Sthirsopaharlepa & 9.Sodhana & 9.Samsana \\
\hline 10.Sandhaniya & 10.Pracchana & 10.Upanaha & 10.Ropana & 10.Vranakaranam \\
\hline 11.Svedana & & 11.Darana & 11.Savanikarma & \\
\hline 12.Samana & & 12.Pidana & & \\
\hline 13.Eshana & & 13.Prakshalana & & \\
\hline 14.Sodhanakasaya & & 14.Vranasodhanlepa & & \\
\hline 15.Ropanakasaya & & 15.Varti & & \\
\hline 16.Sodhan Lepa & & 16.Dhupa & & \\
\hline 17.Ropana Lepa & & 17.Uttsadana & & \\
\hline 18.Sodhan Taila & & 18.Avasadana & & \\
\hline 19.Ropana Taila & & 19.Ksharakarma & & \\
\hline 20.Sodhan Ghrita & & 20.Agnikarma & & \\
\hline 21.Ropana Ghrita & & 21.Vranaropanlepa & & \\
\hline 22.Patrachadan(bahya) & & 22. Vranaropanaghrita & & \\
\hline 23.Patrachadan(abhya) & & 23.vranaropanataila & & \\
\hline 24.Bandhana & & 24.Avachuranan & & \\
\hline 25.Pathyahara & & 25.Svarnakaran & & \\
\hline 26.Utsadana & & 26.Romasanjanana & & \\
\hline \multicolumn{5}{|l|}{ 27.Avasadana } \\
\hline \multicolumn{5}{|l|}{ 28.Ksharakarma } \\
\hline \multicolumn{5}{|l|}{ 29.Agnikarma } \\
\hline \multicolumn{5}{|l|}{ 30.Kathinyakarlepa } \\
\hline \multicolumn{5}{|l|}{ 31.Kathinyaharalepa } \\
\hline \multicolumn{5}{|l|}{ 32.Mrudukaralepa } \\
\hline \multicolumn{5}{|l|}{ 33.Dhupalepa } \\
\hline \multicolumn{5}{|l|}{ 34. Varnyakarma } \\
\hline 35.Ropana & & & & \\
\hline 36.Lomapaharana & & & & \\
\hline
\end{tabular}


Table 6 Lakshana of Ruhyamana Vrana

\begin{tabular}{|c|c|c|c|c|}
\hline Sushruta & Charaka & Astanghridaya & Madhava Nidana & \\
\hline $\begin{array}{l}\text { - Absence of any type of discharge. } \\
\text { - Presence of healthy and new granulation } \\
\text { tissues. } \\
\text { - Yellowish colored wound. }\end{array}$ & $\begin{array}{l}\text { - No any type of } \\
\text { description. }\end{array}$ & $\begin{array}{l}\text { - Done colored without any type } \\
\text { of mucoid secretion. } \\
\text { - Stable. } \\
\text { - Good granulation tissue. }\end{array}$ & $\begin{array}{l}\text { - Blackish white colored. } \\
\text { - Moist less and dry. } \\
\text { - Immobile/stable } \\
\text { granulation tissue. }\end{array}$ & With \\
\hline
\end{tabular}

Table 7 Lakshana of Samyaka Ruddha Vrana

\begin{tabular}{ccc}
\hline Sushruta & Madhava Nidana & Charaka and Vagbhatta \\
\hline & & \\
- Edges: Firmly adhere. & - Edges: Even. & Charaka and Vagbhatta have not given any \\
- Pain: No pain. & - Pain: No pain. & Lakshanas. \\
- Swelling: Not appears. & - Swelling: Not present. & \\
- Leaves cicatrices of the same line with \\
the surrounding skin.
\end{tabular}

\section{Management of Vrana}

Ayurveda science has got a peculiarity in the management of either of the diseases need Chikitsa sutra which is mainly based taking into consideration the involvement of the body as a whole as well as the locally involved tissue. Quite a number of conditions and types of wounds are responsible for early healing, delay healing or incurable stages. Acharyas described the Vrana according to its prognosis.

\section{Treatment of Sadhyovrana}

1. Immediate general treatment pacifying the heat released at the site of injury by special cooling measures due to Pitta aggravation. (Su.Chi.1/4, As.Hr. Ut. 26/7).

2. Snehas-processed by Vata-allaying drugs are advised for loss of blood due to vitiation of Vata following by sudation (Su.Chi. 2/23-25, As.Hr.Ut. 26/6, 12).

3. Irrigation of drugs having cold properties for excessive burning sensation followed by suppuration (Su.Chi.2/2628, As.Hr.Ut. 26/10)

4. Reapproxination of exulted edges-with the help of Honey and Ghee along with cooling measures (As. Hr. Ut. 26/8).

5. Vamana, Virechana, Fasting, Pathyas, Repeated bloodletting are indicated for red and inflamed Vrana. (As.Hr.Ut.26/9).

6. Specific treatment:

A. Ghrista Vrana: Dusting of powder after Subsiding of pain.(As.Hr.Ut. 26/3).

B. Avakrta Vrana: Use of Kalka, Kasaya (As.Hr.Ut.26/14).

C. Vicchinna and Pravilambita: Bandaging and Avapidana after suturing.(As.Hr.Ut.26/15).

D. Viddha Vrana: Salyaharana.

E. Vidalita Vrana: Like Bhagnapratisedha As.Hr.Ut. 26/28.

\section{CONCLUSION}

From the review above, we observe that vranas have been described by different Acharyas in Ayurveda and their treatment vary according to their types and different Acharyas. Though no specific Samprapti regarding Vrana exists in any Ayurvedic text, an attempt is made here to checkout a specific etiopathogenesis of the disease called Vrana.

\section{References}

1. Kaviraj Ambika Dutta Shastri, Sushruta Samhita, Ayurveda Tatwa Sandeepika Hindi Commentry, Chikitsa Sthana, Dvivranayee Adhyaya-1/3, Chukhamba Sanskrit Sansthan, Varanasi, Edition-11, 1997, p1.

2. Kaviraj Ambika Dutta Shastri, Sushruta Samhita, Ayurveda Tatwa Sandeepika Hindi Commentry, Chikitsa Sthana, Dvivranayee Adhyaya-2/86-88, Chukhamba Sanskrit Sansthan, Varanasi, Edition-11, 1997, p26.

3. Kaviraj Ambika Dutta Shastri, Sushruta SamhitaAyurveda tattva sandipka Hindi commentary, Chukhamba Sanskrit Sansthan, Varanasi, reprint edition, sushruta sutra Sthana 21/21;2010

4. Tripathi Brahmanand, Charak Samhita-Charak Chandrika, Hindi Commentry Vol I and II, Chaukhamba Subharti Prakashan, Varanasi, reprinted, Charak Chikitsa Sthana, 25/6; 2003.

5. Kaviraj Ambika Dutta Shastri, Sushruta SamhitaAyurveda tattva sandipka Hindi commentary, Chukhamba Sanskrit Sansthan, Varanasi, reprint edition, Sushruta Sutrasthana 22/6.

6. Tripathi Brahmanand, Charak Samhita-Charak Chandrika, Hindi Commentry Vol I and II, Chaukhamba Subharti Prakashan, Varanasi, reprinted, Charak Chikitsa Sthana,25/7

7. Kaviraj Ambika Dutta Shastri, Sushruta SamhitaAyurveda tattva sandipka Hindi commentary, Chukhamba Sanskrit Sansthan, Varanasi, reprint edition, Sushruta Chikitsasthana 1/3.

8. Tripathi Brahmanand, Charak Samhita-Charak Chandrika, Hindi Commentry Vol I and II, Chaukhamba Subharti Prakashan, Varanasi, reprinted, Charak Chikitsa Sthana, 25/8

9. Kaviraj Ambika Dutta Shastri, Sushruta SamhitaAyurveda tattva sandipka Hindi commentary, Chukhamba Sanskrit Sansthan, Varanasi, reprint edition, Sushruta Chikitsasthana 1/6

10. Kaviraj Ambika Dutta Shastri, Sushruta SamhitaAyurveda tattva sandipka Hindi commentary, Chukhamba Sanskrit Sansthan, Varanasi, reprint edition, Sushruta Chikitsasthana 1/7

11. Prof.Shreekanta murthy, Ashtanga Hridaya, Commented by Arundutta and Hemadri, Chaukhama Sanskrit Series Office, Varanasi, $1^{\text {st }}$ Edition, 1980. Uttarsthana 25/8-9 
12. Kaviraj Ambika Dutta Shastri, Sushruta SamhitaAyurveda tattva sandipka Hindi commentary, Chukhamba Sanskrit Sansthan, Varanasi, reprint edition, Sushruta Chikitsasthana 2/8-9

13. Tripathi Brahmanand, Charak Samhita-Charak Chandrika, Hindi Commentry Vol I and II, Chaukhamba Subharti Prakashan, Varanasi, reprinted, Charak Chikitsa Sthana, 25/17-19.

14. Kaviraj Ambika Dutta Shastri, Sushruta SamhitaAyurveda tattva sandipka Hindi commentary, Chukhamba Sanskrit Sansthan, Varanasi, reprint edition, Sushruta Sutrasthana 22/7.

15. Tripathi Brahmanand, Charak Samhita-Charak Chandrika, Hindi Commentry Vol I and II, Chaukhamba Subharti Prakashan, Varanasi, reprinted, Charak Chikitsa Sthana,25/24-25

16. Prof.Shreekanta murthy, Ashtanga Hridaya, Commented by Arundutta and Hemadri, Chaukhama Sanskrit Series Office, Varanasi, $1^{\text {st }}$ Edition, 1980. Uttarsthana. 25/2-4
17. Madhava Nidana with Madhukosha Sanskrit and Vidyotini, Hindi commentary by Sudarshan Shastri, Chaukhamba Sanskrit Sansthan. Ch. 42/7

18. Tripathi Brahmanand, Sharangdhar Samhita with "Dipika Hindi Commentary", Edited by Brahmanand Tripathi; Reprint 2008. Charkhamba Subharti Prakashan, Varanasi, Ch.17/71-74.

19. Tripathi Brahmanand, Charak Samhita-Charak Chandrika, Hindi Commentry Vol I and II, Chaukhamba Subharti Prakashan, Varanasi, reprinted, Charak Chikitsa Sthana, 25/29-30, 36-37

20. Tripathi Brahmanand, Charak Samhita-Charak Chandrika, Hindi Commentry Vol I and II, Chaukhamba Subharti Prakashan, Varanasi, reprinted, Charak Chikitsa Sthana, 25/27.

21. Kaviraj Ambika Dutta Shastri, Sushruta SamhitaAyurveda tattva sandipka Hindi commentary, Chukhamba Sanskrit Sansthan, Varanasi, reprint edition, Sushruta Sutrasthana 22/5-9.

\section{How to cite this article:}

Ganapthirao.I et al (2017) ' The Concept Of Vrana - A Review', International Journal of Current Advanced Research, 06(04), pp. 3239-3247. DOI: http://dx.doi.org/10.24327/ijcar.2017.3247.0235 